\title{
The Pioneering Research Practices of Designer Janja Lap
}

\author{
Predan B ${ }^{1}$, Šubic Š 2,* \\ 1. University of Ljubljana, Academy of Fine Arts and Design, Ljubljana, Slovenia \\ 2. Museum of Architecture and Design, Ljubljana, Slovenia \\ * Correspondence: Špela Šubic spela.subic@mao.si
}

\section{Citation: Predan B, Šubic Š. The} pioneering research practices of designer Janja Lap. Proceedings of Socratic Lectures. 2021; 6: 138-146. https://doi.org/10.55295/PSL.2021.D. 018

Publisher's Note: UL ZF stays neutral with regard to jurisdictional claims in published maps and institutional affiliations.

Copyright: (c) 2021 by the authors. Submitted for possible open access publication under the terms and conditions of the Creative Commons Attribution (CC BY) license (https://creativecommons.org/license s/by/4.0/).

\begin{abstract}
:
Janja Lap (1929-2004) is known to the Slovenian professional public as a first-rate glass designer and industrial designer in the field of electro-optical device development. For most of her professional life she was also a devoted researcher in the field of design, yet this facet of her work remained largely overlooked by both the professional and general public until the beginning of 2021, when the Museum of Architecture and Design acquired her archive. In this text we attempt to show that what sets her research apart is the way it thoughtfully weaves together two scientific approaches to design that each characterise a different school: one the Faculty of Architecture in Ljubljana and the other the Royal College of Art (RCA) in London. In other words, we can trace in her work the intertwining of two threads of knowledge: one arising from the architectural and urbanistic background she acquired during her studies under the mentorship of Edvard Ravnikar in what was then Yugoslavia, and the other obtained at the RCA under the mentorship of Bruce Archer, the British mechanical engineer and the first professor to devote himself to systems-level research in design, and Sir Misha Black, a pioneer in the development of scientific research approaches in the field of design.
\end{abstract}

Keywords: Janja Lap; Slovene design; Ljubljana School of Architecture; Edvard Ravnikar, Sir Misha Black; 


\section{Introduction}

After the Second World War, the Yugoslav economy was in a process of massive industrial expansion. Slovenia was undergoing an intensive transformation from an agricultural society to an industrial one. The political-economic system had transitioned from the pre-war capitalism to socialism. Nationalisation and the consolidation of individual production facilities into larger factories geared towards mass production required a different development direction with modified approaches and different results. The large-scale push towards industrialisation had the most success in those industries that had a tradition going back to the pre-war period, among them the wood, textile and glass industries. All industries had to maintain a level of productivity that allowed meeting the country's need for foreign currency, while at the same time reorienting themselves towards a new way of developing and manufacturing modern industrial products.

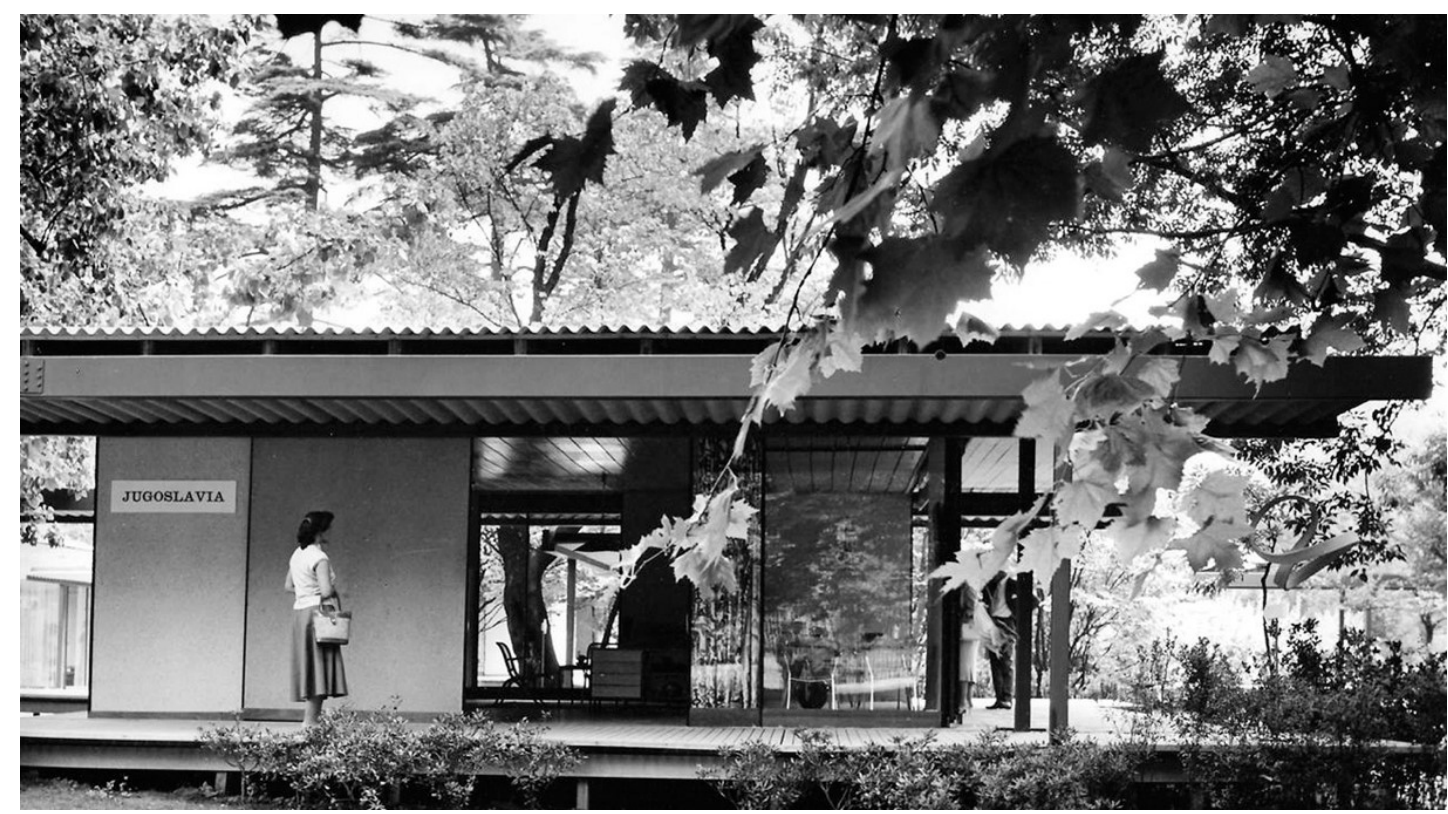

Figure 1. The Yugoslav pavilion at the XI. Triennale in Milano, 1957, photo: Janez Kališnik. (From MAO photo library, F1110)

In addition to the above, there is another factor crucial for the understanding of the Yugoslav path towards industrialisation paved with socialism, namely the active integration of society with the aim of establishing an alternative to the prevailing ideology of the time, which entailed the division of the world into blocs in a perpetual state of Cold War. After 1948, Yugoslavians chose to reject both of the major blocs' ideologies - the ideology of Western capitalism, as well as the state socialism of the East. In the former, the problem they identified was that in capitalism, the integration of society is mostly carried out by the market, with partial assistance from the state. In centrally planned socialist societies, by contrast, this integration is predominantly a responsibility of the state, with partial assistance from the market (Kavčič, 1987). Consequently, in Yugoslavia in the $50 \mathrm{~s}$ and especially the 60s, the path beyond bloc politics was represented by the non-aligned movement, while the alternative in the area of the sociology of work was built on the idea of socialist self-management. All of the above also proved vital for the further professionalisation and development of Slovenian design.

There was at the time a growing awareness among the designers of the urgent need to bring about the conditions for developing, designing and manufacturing higher-quality everyday products, joined by a desire for their profession to have a role in industrial production. The furniture pieces exhibited by domestic producers at fairs were 
criticised by the young architects as ill-suited to modern types of housing. The only producer to stand out was the Stol factory, the first in Yugoslavia to employ a designer (in 1952), followed by manufacturers such as Iskra, Gorenje and others. In the same period - beginning with 1948-a need to establish a system of higher education for industrial designers became apparent. One of the main initiators of this movement was Edvard Ravnikar, an architect and a professor to the protagonist of this text, the designer and architect Janja Lap.

\section{The background of the study and research methods}

After the Second World War, the foremost researchers in the field of design in Slovenia included the architect Branka Tancig, whose research involved, among other topics, the concept of the "laboratory" kitchen (Tancig-Novak, 1958; 1971), architects France and Marta Ivanšek, whose research focused on dwellings and their furnishings (Ivanšek, 1959; 1960), and the sculptor and industrial designer Ciril Cesar, who, inspired by the design research institutes at The Ulm School of Design (Hochschule für Gestaltung Ulm) in Germany, sought ways to introduce research into the economy, which in his case meant the producer of household appliances Gorenje (Berg et al., 1978).
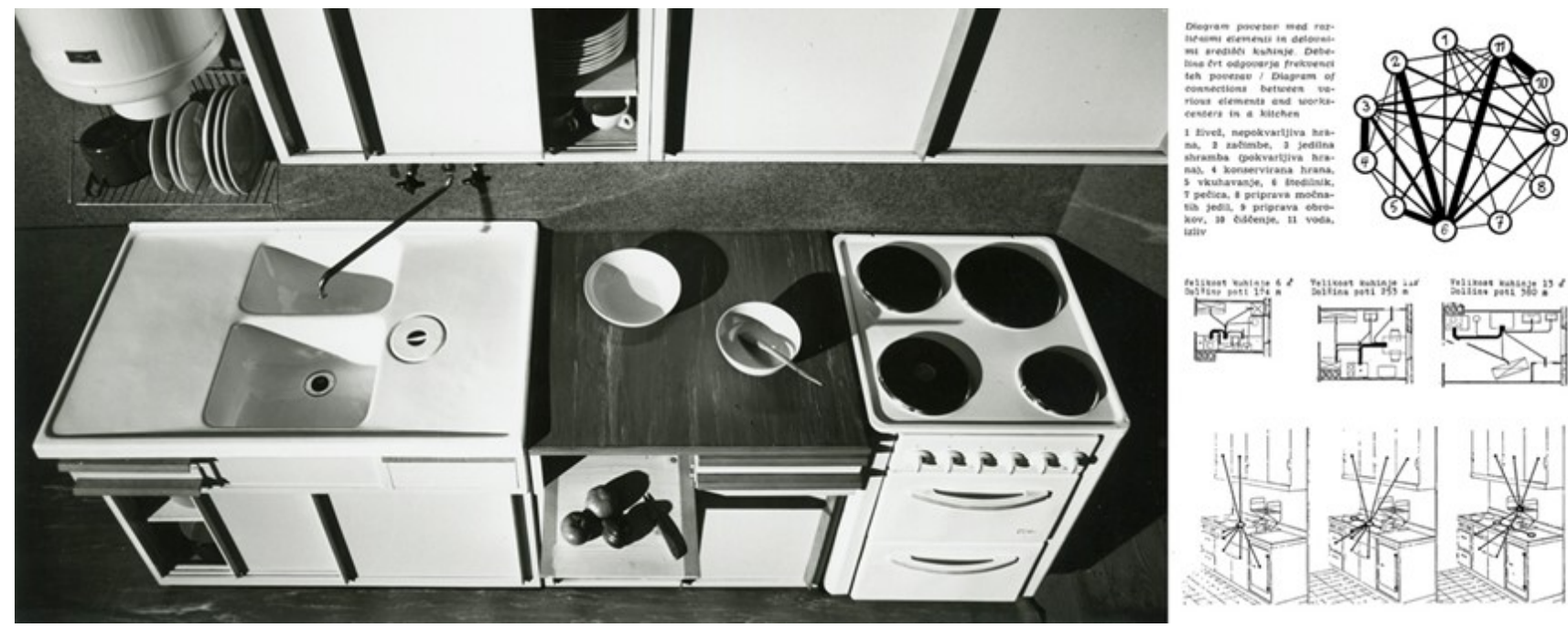

Figure 2. The "laboratory" kitchen of designer Branka Tancig with a study into the patterns of movement within the kitchen, 1958, photo: Janez Kališnik. (From MAO photo library, F7, and Tancig 1953).

In contrast to the researchers listed above, Janja Lap and her work remained largely unknown until today. The only record of her research can be found in a 1980 issue of the Belgrade magazine Industrial Design, where Lap summarised the research that had been carried out and the potential it held (Lap, 1980). Yet further investigation and intensive examination of the archives led to the discovery of the rest of her extensive and systematically preserved scientific research. The present text is based on the analysis and interpretation of the impact of her research studies and personal documents. Between January and October 2021, we also conducted a series of semi-structured interviews with her son, as well as with students from the period when she was teaching and researching in the UK, as we wished to understand the broader context of her work and research. In this text we focus in particular on her unpublished research studies and other unpublished documents in the archive, such as study materials, preparatory materials for research, detailed research funding applications, and numerous biographical and bibliographical records. These bear witness to the restless spirit of a designer who constantly sought out new opportunities that would allow her to carve out a niche for herself, as well as challenge her to pursue further research. 


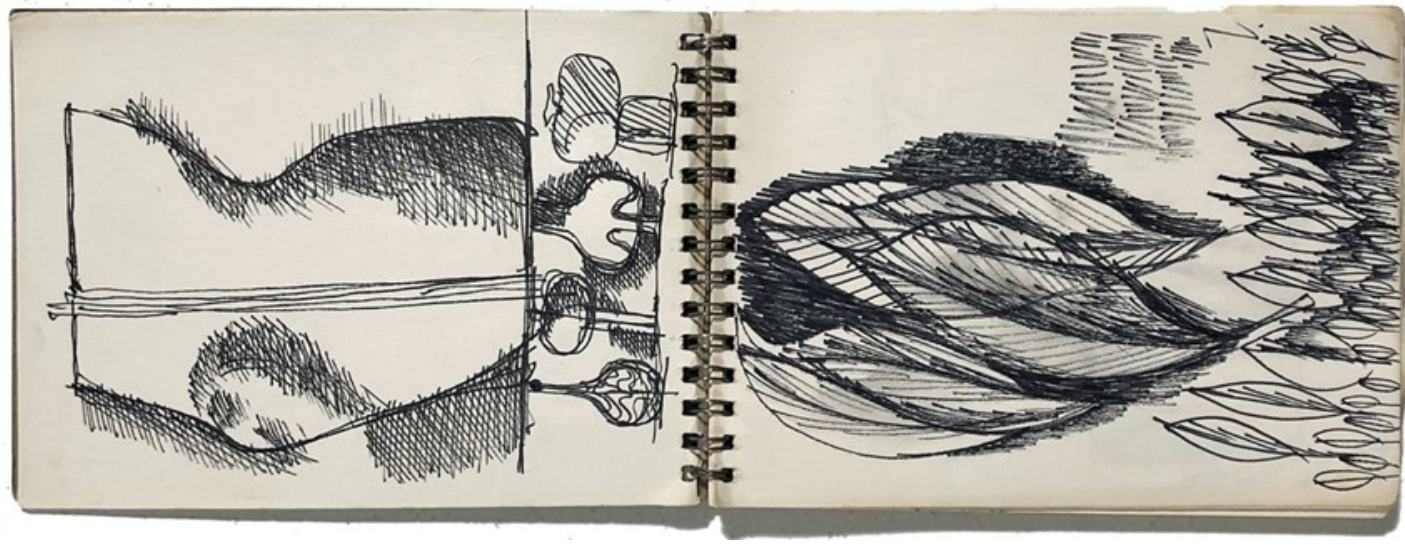

Figure 3. Janja Lap's sketchbook.

The results of the study, which lasted for several months, paint a picture of an exceedingly astute researcher and a first-rate designer. She was born in 1929 in Ljubljana, in what was then the Kingdom of Yugoslavia; Janja Lap's father was Anton Lap, an engineer, who was the head of landscaping in Ljubljana and a close associate of the domestically and internationally acclaimed architect Jože Plečnik. He collaborated with the latter in practically all of his projects in Ljubljana that involved planting and landscaping. Her childhood admiration for Plečnik as a master of his craft ended up influencing her decision to study architecture. During her studies at the Faculty of Architecture, Civil and Geodetic Engineering in what had by then become the Socialist Federal Republic of Yugoslavia, Lap soon proved to be a diligent student, becoming first an assistant to the architect and professor Edvard Ravnikar and eventually his colleague.

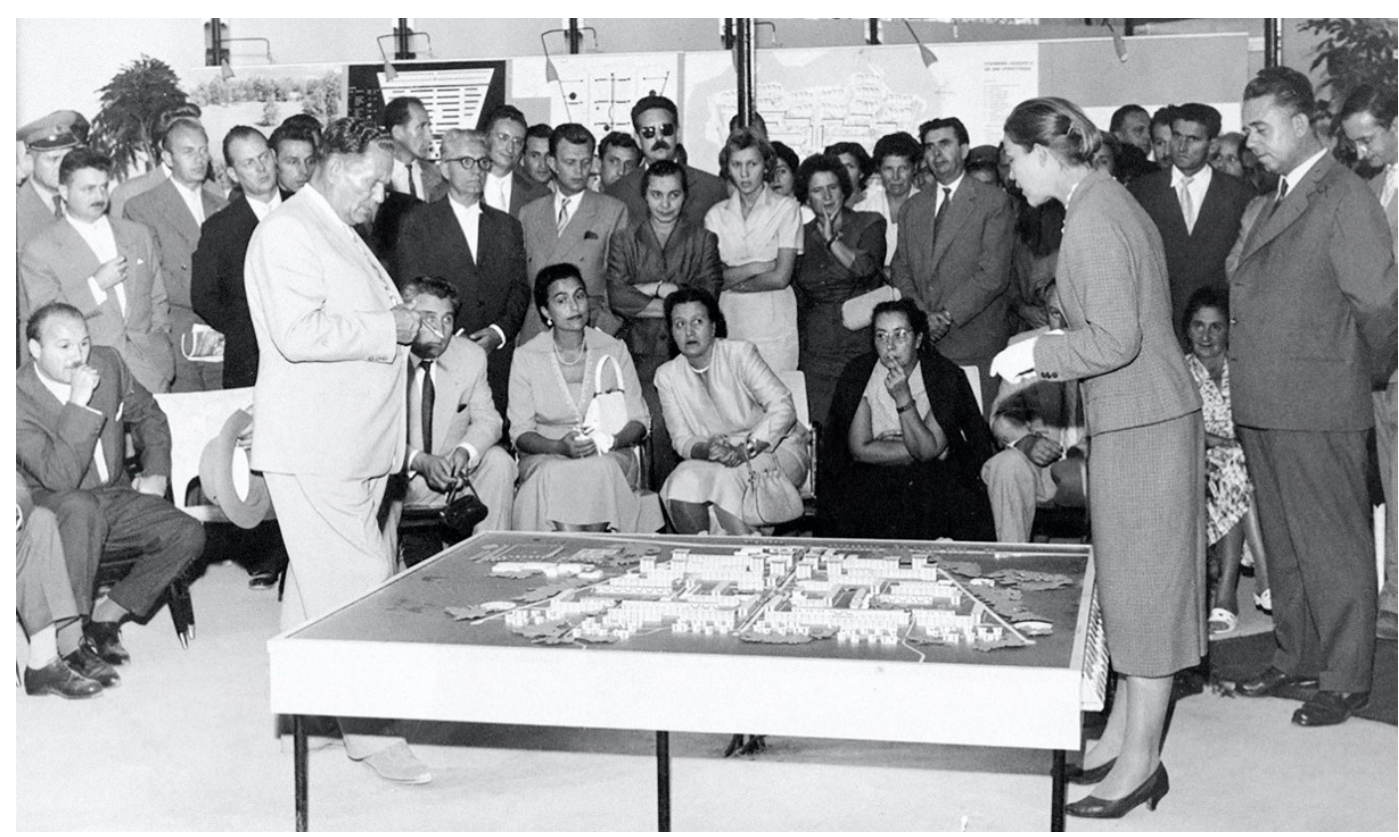

Figure 4. Janja Lap presenting a project for a 7000-person housing estate 1958. Left to right: Večeslav Holjevac, Josip Broz - Tito, Aleksandar Ranković, Jovanka Broz, Pepca Kardelj, Lidija Šentjurc and Janja Lap. (From Jeffs, XXXX). 
In 1956, she graduated with a first degree and five years later with a second. In 1964, following a brief stint at the Secondary School of Design and Photography in Ljubljana, she joined a research team at the Royal College of Art (RCA) in London with a scholarship from the British Council. Until 1977, save for a few short breaks, she remained a permanent resident of the United Kingdom, where, among other things, she completed Master's level studies at the RCA, lectured at the University of Sheffield, engaged in creative work and, above all, researched extensively. Upon her return to Slovenia she first worked as a researcher in the field of social issues in housing construction at the Institute of Sociology and Philosophy at the University of Ljubljana. In 1979, she began a 10-year stint at Iskra as a designer of electro-optical devices. In 1990, she received the title of assistant professor for the subject "Applied Arts: Glass". In the period shortly before Slovenian independence, she lectured at the University of Mosul in Iraq as part of the treaties among the non-aligned countries; afterwards, she worked until her retirement at the Faculty of Education in Ljubljana and at the Slovenian branch of the Open University.

In 1956, she graduated with a first degree and five years later with a second. In 1964, following a brief stint at the Secondary School of Design and Photography in Ljubljana, she joined a research team at the Royal College of Art (RCA) in London with a scholarship from the British Council. Until 1977, save for a few short breaks, she remained a permanent resident of the United Kingdom, where, among other things, she completed Master's level studies at the RCA, lectured at the University of Sheffield, engaged in creative work and, above all, researched extensively. Upon her return to Slovenia she first worked as a researcher in the field of social issues in housing construction at the Institute of Sociology and Philosophy at the University of Ljubljana. In 1979, she began a 10-year stint at Iskra as a designer of electro-optical devices. In 1990, she received the title of assistant professor for the subject "Applied Arts: Glass". In the period shortly before Slovenian independence, she lectured at the University of Mosul in Iraq as part of the treaties among the non-aligned countries; afterwards, she worked until her retirement at the Faculty of Education in Ljubljana and at the Slovenian branch of the Open University.

Even this brief and highly abbreviated overview of her life attests to her exceptional learning capacity, highly pronounced curiosity and ability to identify new challenges. It is no wonder, then, that on her arrival in London (1964) she integrated so well into the research community at the RCA, which at the time was a pioneering one. It was then that she first demonstrated a desire and aptitude for researching and designing complex systems-systems that go beyond the mere transformation of products and services for a single entity; she continuously focused on understanding and designing a holistic approach in the broader social and geographical space. Our study revealed that her work demonstrates a commingling of two approaches to design research, each characteristic of a particular school: one the Faculty of Architecture in Ljubljana and the other the RCA in London. In other words, we can trace in her work the intertwining of two threads of knowledge: one arising from the architectural and urbanistic background she acquired during her studies and later through her close collaboration with the architect Edvard Ravnikar, and the other obtained at the RCA under the mentorship of Bruce Archer, the British mechanical engineer and the first professor to devote himself to systems-level research in design. What was crucial for the development of scientific research approaches in design, however, was the work of Sir Misha Black, who had an immense influence on the education approaches in the field of industrial design at the RCA; his work served as the foundation of the new academic discipline of design research. During her time in Great Britain, Janja Lap was a close associate of both of these scholars. She worked with Professor Black in a research group that focused on hospitals; six years later, Professor Archer was her thesis advisor when she was writing her Master's thesis with the title Communal Feeding System (Lap, 1973).

In the preface to the article titled Communal Feeding, which was published in 1980 in the magazine Industrial Design, Janja Lap articulated her interest in the field of research in design. She wrote that her central interest was "in the impact of industrial design on the systems-level issues of a given social standard" (Lap, 1980). With this she secures her place in a noble tradition of architects and designers who worked and studied in the years 
after the Second World War and who consciously chose as the central mission of their work the gradual modernisation of the living environment, raising the standard of living and contributing to the development of technical culture (Ivanšek, 1951). Her subsequent efforts should all be interpreted in this light. For instance, when she undertook research into communal feeding systems in hospitals within the research group led by Professor Misha Black, she focused her efforts on the critical analysis and understanding of the advantages and disadvantages of existing hospital feeding schemes. During her in-depth research into the topic she not only identified numerous deficiencies in the existing systems; she also discovered that in the established systems, the time between the preparation and consumption of food led to a loss of its nutritional value in terms of vitamins and other nutrients. She found this was not only due to the time factor, but also because of the need for reheating and transfer of food, as well as inappropriate means of transport and meal serving. These discoveries forced her to come up with a unique approach to solving a recognised problem that she had first very precisely and systematically analysed.
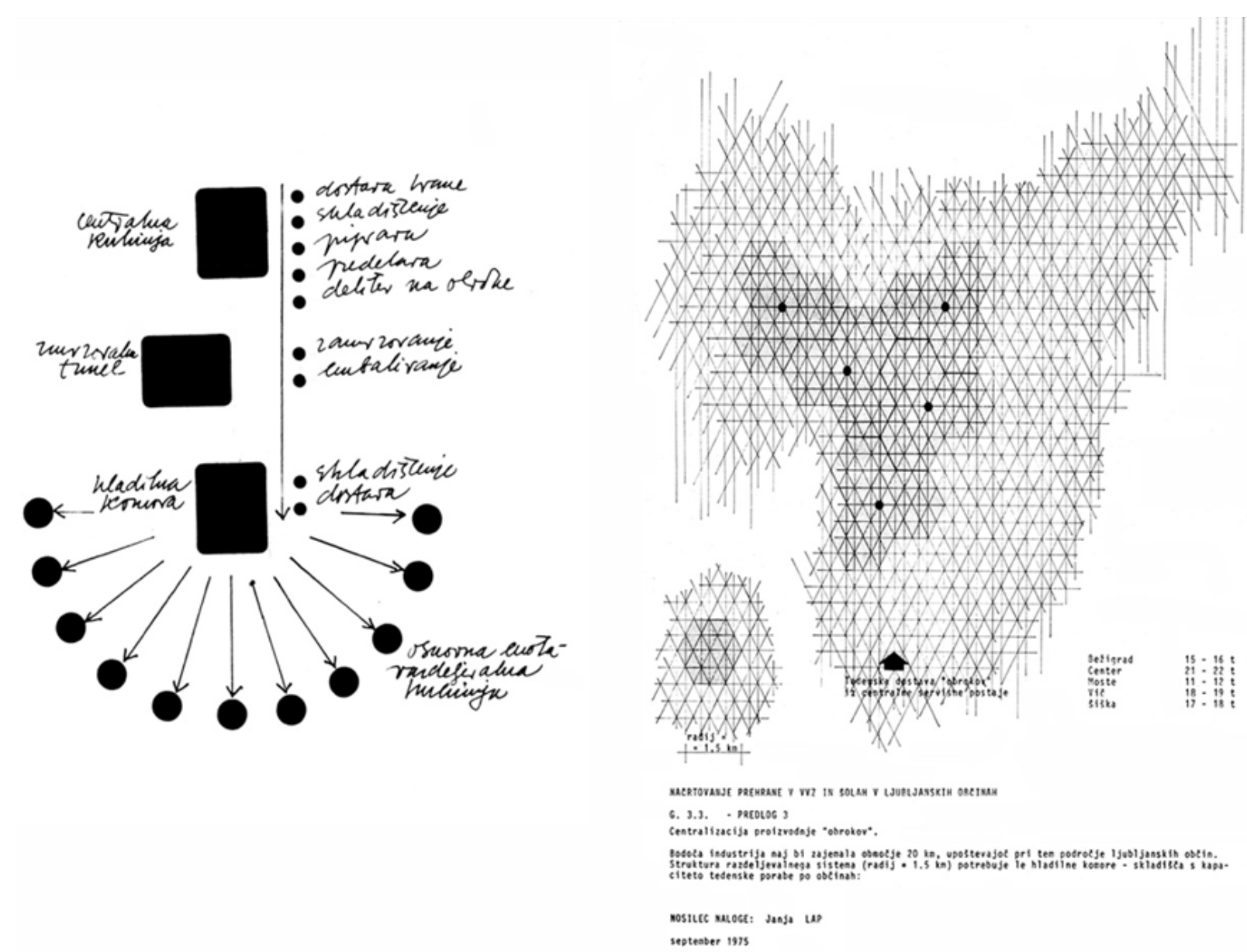

Figure 5. Janja Lap, proposal for the introduction of central kitchens for the purpose of meal planning in kindergartens and schools in the municipality of Ljubljana, schematic illustrations.

Let us briefly illustrate two premises. She carefully elaborated the identified issue-transport in the context of addressing the complex problem of increasing the quality of food provided in community programmes to the most vulnerable groups (the young, elderly and sick) - on the basis of Ravnikar's conception of the functionalist city, an idea that "strived towards order and good organisation in all the vital functions of the city. According to these principles, all the operations of the city can be categorised into one of 
the four functions: habitation, work, leisure and traffic, the latter as the junction of the first three" (Žnidaršič, 2004). Through careful planning of the use of urban road networks, Janja Lap devised a system for rapid and efficient delivery of meals to designated institutions, which allowed for the relocation of the main food preparation facilities to the outskirts of the city. For her, however, the organisational matrix of the city served only as the basic premise for a further expansion of systems-level design principles.

In the course of the research, her findings compelled Janja Lap to change her approach. Whereas initially she focused on the design of an adaptable container that would enable transporting the meal rapidly and safely, in the subsequent steps the idea of the service as a system assumed an increasingly central role in her research and redesign efforts. In her research and design, she focused on the end user - whose desire is to receive a healthy and quality meal - as well as all those involved in preparing and serving the meal (from the cooks and those who dispensed the food into pots, to the delivery workers). In doing so, Lap approached the design process in a way typical of a service designer; it is necessary to note, however, that while such systems-level approaches to problem solving had already begun to be introduced at the time, the discipline of service design would only begin to be discussed at a formal level in 1995 in Germany (Mager, 2021). Janja Lap, by contrast, underwent this shift in thinking in the early 1970s; this clarifies the claim she made in her master's thesis - that in her research "she devised a new approach to a recognised design problem" (Lap, 1974).

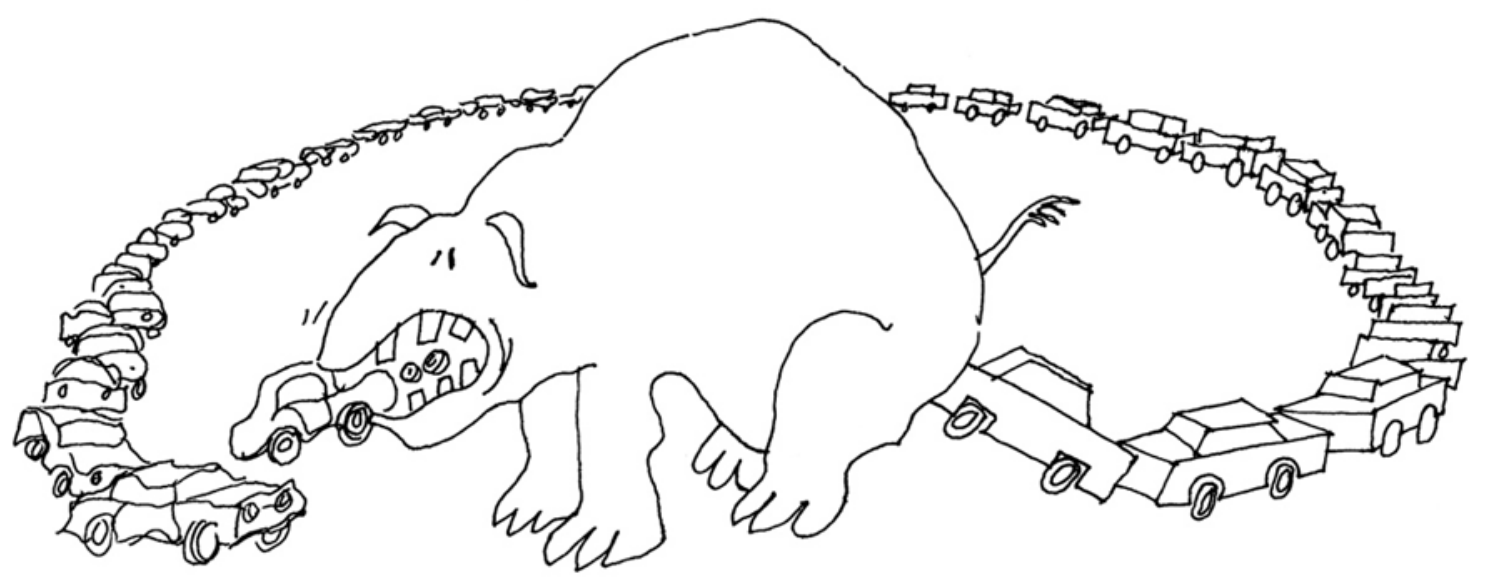

Imagine glass dishes!!!

Figure 6. Janja, Lap's, illustration of circular design in the master's thesis.

It was this transition from the micro- to the macro level that facilitated another one of Janja Lap's insights into systems-level issues: in 1971, on the basis of in-depth studies, she astutely recognised the social problem, nowadays of acute importance, of the world's dependence on single-use packaging (Lap, 1971). Wishing to overcome this problem, she devised a container that could handle rapid freezing and reheating of food while also being suitable for serving and eating the food. But she did not stop there. She also highlighted the urgent need to have a system in place for the time when the container wears out and needs to be discarded. She was convinced that as the community feeding system is introduced, a system should be instituted that would involve the collection of discarded containers and cleaning of the material, as well as its further processing (Lap, 1971; 1980). With this proposal, she entered the nowadays highly relevant fields of circular economy and reverse logistics. 


\section{Discussion}

Tangible results of her research can be encountered in Slovenia as well. In 1972, under the auspices of the Central Institute for Home Economics, she was commissioned by the Chamber of Commerce of the then Socialist Republic of Slovenia (SR Slovenia) to prepare a programme for a research study titled Certain Transport and Distribution Systems for Collective Feeding (Lap, 1972). The proposal included the results of her research at RCA, adapted, for the Slovenian milieu. Three years later, the Union of Child Care Associations of the SR Slovenia commissioned her to prepare the research study The Introduction of an Industrial-style Catering System in Education-Day Care Institutions and Schools in the Municipality of Ljubljana (Lap, 1975). With this analysis she provided a concrete view of the problems encountered on the ground and used them to identify what the needs were. She looked at them from three perspectives (ideal situation, existing situation, an adaptation of the existing situation).

Partial results of her research were later published in Polde Maček's article Community Feeding in the SR Slovenia, Central Preparation and Distribution and in the Official Gazette at the end of 1979 in the article Views, conclusions and recommendations for the formulation and implementation of policy in the field of community feeding and provisioning in the SR Slovenia (Arhiv Republike Slovenije 1277, 1979). The 1978 document included, among other things, proposals for an externally located facility for centralised thermal processing of meals, with consideration given to distribution routes and delivery, as well as the possibility of deep-freezing food. These are not the work of Janja Lap alone, but her efforts have undoubtedly been an important piece of the puzzle in the development of an understanding that there is a need for a sensible and systemic upgrade of the existing infrastructure.

\section{Conclusions}

It is important to point out that, building on long years of research in the field of design, Janja Lap eventually developed a unique analytical approach to addressing a previously identified problem. She succeeded in incorporating the principles of systems-level, service and circular design, all highly relevant nowadays, in her research and planning, while placing everything firmly into the context of Ravnikar's conception of the functionalist city. In light of today's remarkable expansion of methodological approaches in the aforementioned areas of research in design, the methods described in her pioneering research work seem exceptionally progressive for the mid-1960s and early 1970s period and retain their relevance today.

Acknowledgements: The article is a result of the research project J7-2606, Models and practices of international cultural exchange within the Non-Aligned Movement: researching the spatio- temporal cultural dynamics, and the research and exhibition project of the Museum of Architecture and Design of Ljubljana.

Conflicts of Interest: The authors declare no conflict of interest.

\section{References}

1. Arhiv Republike Slovenije 1277 Kardelj Edvard - Krištof, 1926-1990, 158-367. Maček, P., Družbena prehrana v SR Sloveniji, centralna priprava in distribucija, I. faza. [Community Feeding in the SR Slovenia, Central Preparation and Distribution, phase 1] Ljubljana, Združena podjetja živilske industrije, 1978.

2. Arhiv Republike Slovenije 1277 Kardelj Edvard - Krištof, 1926-1990, 158-370. A photocopy of the article Views, conclusions and recommendations for the formulation and implementation of policy in the field of community feeding and provisioning in the SR Slovenia. Official Gazette of the SR Slovenia, no 1, 13 January 1979

3. Berg F, Wolf K, Maser S, Cesar C. DE-institut ‘80. Aufgaben und Organisation eines Design Institutes in der Industrie. Braunschweig, SHFBK, 1978.

4. Ivanšek F. Stanovanjsko raziskovanje na Švedskem [Housing Research in Sweden]. Ljubljana, Stanovanjsko komunalni center, 1959.

5. Ivanšek F. Stanovanje in potrošnik (rezultati ankete stanovanjskih želja 1960) [The Dwelling and Its Buyer (results of the 1960 survey of housing preferences)]. Ljubljana, Urbanistični inštitut LR Slovenije, 1960. 
6. Ivanšek F.Oblikovanje v industriji [Design in Industry]. Arhitekt, 1951, 1/1: 26-29.

7. Jeffs N. Personal archive.

8. Kavčič B. Sociologija dela [Sociology of Work]. Ljubljana, Delavska enotnost, 1987, pp. 325.

9. Lap J. Application to take a Master's Degree by Project in the School of Industrial Design (Engineering). London, RCA, 1971.

10. Lap J. Določeni transportni in razdeljevalni sistemi kolektivne prehrane, typed manuscript [Certain Transport and Distribution Systems for Collective Feeding]. Ljubljana, CZNG, 1972.

11. Lap J. Master's Degree by Project: Communal Feeding System. Department of Design Research, Royal College of Art, 1973. The archive of Nikolai Jeffs.

12. Lap J. Whittlestone, P. Way to Community Catering, typed manuscript. Architectural Association School of Architecture, 1974.

13. Lap J. Uvedba industrijskega načina preskrbe prehrane v vzgojno-varstvenih zavodih in šolah v ljubljanskih občinah [The Introduction of Industrial-style Catering System in Education-Day Care Institutions and Schools in the Municipality of Ljubljana]. Ljubljana, Zveza skupnosti otroškega varstva SR Slovenije, 1975.

14. Lap J. Objekti društvene ishrane - Polazne osnove za rešenje dizajn problema. Industrijsko oblikovanje, 1980, 11/57-58: 37-39.

15. Mager B. My Journey with Service Design. 2019. Accessed 28 April 2021. Available from www.service-design-network.org/community/birgit-mager-4178.

16. MAO photo library, F1110. Accessed XXXX

17. Tancig - Novak B. Kuhinja: načrtovanje in oprema [Kitchen: Planning and Furnishing]. Ljubljana, Centralni zavod za napredek gospodinjstva, 1958.

18. Tancig - Novak B. Načela za oblikovanje kuhinjskega kompleta in kuhinjskega prostora v stanovanju: Raziskovalna naloga s področja industrijskega oblikovanja stanovanjske opreme in s področja racionalizacije gradnje stanovanj [Principles for the design of the kitchen suite and kitchen space in a residence: a research assignment in the fields of industrial design of furnishings and rationalisation of housing construction]. Ljubljana, Centralni zavod za napredek gospodinjstva, 1971.

19. Žnidaršič R. Edvard Ravnikar's Design Method: the Architect's Procedures for Adapting to Changing Planning Conditions. AB, 2004, 34/165-166: 8-33. 